\title{
ANALISIS PERBANDINGAN ECONOMIC VALUE ADDED (EVA) DAN FINANCIAL VALUE ADDED (FVA) SEBAGAI ALAT UKUR PENILAIAN KINERJA KEUANGAN PADA INDUSTRI PERKEBUNAN DI BURSA EFEK INDONESIA
}

\author{
Nora Alverniatha ${ }^{1}$ \\ BINUS Business School \\ Samuel Dossugi ${ }^{2}$ \\ Universitas Atma Jaya Jakarta
}

\begin{abstract}
Economic Value Added (EVA) and the Financial Value Added (FVA) is the concept of management performance assessment based on the size of the added value created by the company during the specified period. EVA measures the economic profit of the company taking into account the cost of capital, whereas FVA earnings measure taking into account the contribution of fixed assets in generating net profits of the company. The study aims to determine the ratio of Economic Value Added (EVA) and the Financial Value Added (FVA) as a measure of financial performance assessment on the industrial estates listed in Indonesia Stock Exchange for the period 2004 to 2009. The method used is descriptive analysis method using time series data.

The results of this study indicated that companies using EVA to create economic value and have a good financial performance from 2004 until 2009. While using the FVA, the company is also able to create a positive financial value of good financial performance from 2004 until 2009. The results also show that there are significantly differences between the EVA and the FVA for the period 2004 to 2009.
\end{abstract}

Keywords: Economic Value Added (EVA), Financial Value Added (FVA), industrial estates, financial performance.

\footnotetext{
${ }^{1,2}$ Nora Alverniatha is an alumni of BINUS Business School (nora.alverniatha@gmail.com) and Samuel Dossugi is faculty of Universitas Atma Jaya Jakarta (dossugi@hotmail.com).
} 


\section{PENDAHULUAN}

Sesuai dengan Rencana Pembangunan Jangka Menengah Nasional (RPJM) 2010-2014, sebelas prioritas pembangunan ekonomi yang salah satunya adalah Revitalisasi Pertanian dan Perdesaan, yang ditujukan untuk: (a) meningkatkan peran sektor pertanian dalam perekonomian nasional, (b) menciptakan lapangan kerja berkualitas di pedesaan, khususnya lapangan kerja non pertanian, yang ditandainya dengan berkurangnya angka pengangguran terbuka dan setengah terbuka, dan (c) meningkatkan kesejahteraan petani, nelayan dan masyarakat pedesaan yang dicerminkan dari peningkatan pendapatan dan produktivitas pekerja di sektor pertanian.

Sektor pertanian mempunyai peranan yang cukup penting dalam kegiatan perekonomian di Indonesia, hal ini dapat terlihat kontribusinya yang cukup besar terhadap Produk Domestik Bruto (PDB) Indonesia yang selalu menempati urutan kedua atau ketiga setelah sektor industri pengolahan dan perdagangan, hotel dan restoran.

Perkebunan sebagai bagian integral dari sektor pertanian merupakan salah satu sub sektor yang mempunyai peranan penting dan strategis dalam pembangunan nasional. Peranannya terlihat nyata dalam penerimaan devisa negara melalui ekspor, penyediaan lapangan kerja, pemenuhan kebutuhan konsumsi dalam negeri, bahan baku berbagai industri dalam negeri, perolehan nilai tambah dan daya saing serta optimalisasi pengelolaan sumberdaya alam secara berkelanjutan.

Dari beberapa komoditas perkebunan yang penting di Indonesia (karet, kelapa sawit, kelapa, kopi, kakao, teh, dan tebu), kelapa sawit, tumbuh lebih pesat dibandingkan dengan tanaman perkebunan lainnya dengan laju pertumbuhan di atas $5 \%$ per tahun.Sejak beberapa tahun terakhir, komoditas kelapa sawit telah menggeser posisi kayu dan produk-produk olahannya sebagai produk andalan hasil hutan Indonesia. Bahkan, Indonesia telah menjadi negara penghasil minyak kelapa sawit atau crude palm oil (CPO) terbesar.

Prospek pasar minyak sawit diprediksikan masih akan sangat cerah, antara lain karena masih tingginya permintaan dunia dan selalu berkembangnya jumlah luas areal perkebunannya dan produksinya dari tahun ke tahun. Melihat banyaknya permintaan akan minyak sawit di dunia dan demikian menariknya prospek pasar dan masih relatif 
terbukanya potensi pasar produksi kelapa sawit di Indonesia, membuat persaingan dalam industri ini semakin ketat.

Ketatnya persaingan menyebabkan perusahaan harus memiliki strategi bersaing yang unggul agar dapat bertahan dan meningkatkan pangsa pasarnya. Hal ini membuat perusahaan-perusahaan go public tersebut harus lebih meningkatkan kinerjanya dengan tetap berupaya untuk meningkatkan volume penjualan melalui pengembangan pasar, baik dalam maupun luar negeri serta melakukan efisiensi disetiap aspek dimana strategi fundamental sangat berperan dalam memenangkan persaingan dalam industri ini.

Mengingat bahwa strategi fundamental itu penting untuk pengembangan perusahaan maka manajer keuangan perlu memiliki data pengukuran yang mencerminkan kinerja keuangan untuk mengetahui apakah perusahaan yang bersangkutan telah melakukan proses memaksimalkan nilai perusahaan. Pengukuran

tersebut dapat dijadikan dasar bagi manajemen perusahaan dalam pengelolaan modalnya, rencana pembiayaan, wahana komunikasi dengan pemegang saham serta dapat digunakan sebagai dasar dalam menentukan insentif bagi karyawan. Dengan value based sebagai alat pengukur kinerja perusahaan, manajemen dituntut untuk meningkatkan nilai perusahaan. Pengukuran value added yang telah banyak dikemukakan dalam beberapa tulisan maupun penelitian adalah Economic Value Added (EVA). Paradigma pengukuran value added yang belum begitu banyak dikemukakan adalah Financial Value Added (FVA).

\section{Ruang Lingkup}

Penelitian agar lebih terarah dan tidak menyimpang dari pembahasan dan analisis, penulis membatasi pada hal-hal sebagai berikut :

a. Data yang digunakan untuk penelitian adalah laporan keuangan perusahaan-perusahaan yang bergerak diindustri perkebunan yang terdaftar di Bursa Efek Indonesia dalam kurun waktu 6 tahun dari tahun 2004 - 2009 diantaranya:

1. PT Astra Agro Lestari Tbk

2. PT SMART Tbk

3. PT Tunas Baru Lampung Tbk

4. PT Bakrie Sumatera Plantations Tbk

5. PT London Sumatera Indonesia Tbk

Sedangkan untuk perusahaan berikut ini tidak dapat diolah data keuangannya, dikarenakan keterbatasan data:

1. PT Gozco Tbk 
2. PT Sampoerna Agro Tbk

3. PT BWPlantation Tbk

b. Penelitian ini dilakukan untuk mengetahui kinerja keuangan perusahaan-perusahaan yang bergerak diindustri perkebunan yang terdaftar di Bursa Efek Indonesia dengan menggunakan metode Economic value Added dan Financial value Added.

\section{RUMUSAN MASALAH}

Permasalahan yang akan di bahas dalam penelitian ini adalah :

1. Bagaimana kinerja keuangan perusahaan-perusahaan go public pada industri perkebunan jika diukur dengan menggunakan metode EVA?

2. Bagaimana kinerja perusahaan-perusahaan go public pada industri perkebunan jika diukur dengan menggunakan metode FVA?

3. Bagaimana hasil perbandingan EVA dan FVA sebagai alat ukur penilaian kinerja keuangan pada perusahaan-perusahaan go public pada industri perkebunan?

\section{LANDASAN TEORI}

\section{EVA}

Economic Value Added merupakan sebuah ukuran laba ekonomis yang dapat ditentukan dari selisih antara Laba Bersih Operasional Setelah Pajak (Net Operating Profit After Tax) dengan biaya Modal. Biaya modal ini ditentukan melalui biaya rata-rata tertimbang dari Hutang dan Ekuitas (Weighted Average Cost of Debt and Equity Capital - "WACC") dan jumlah dari modal yang digunakan (Stewart, 2010).

Cara menghitung EVA adalah seperti di bawah ini (Young, 2001, p34) : Net Sales

- $\quad$ Operating expenses

$=\quad$ Operating profit ( earnings before interest and tax (EBIT))

- Taxes

$=\quad$ Net operating profit after tax (NOPAT)

- $\quad$ Capital charges (invested capital $x$ cost of capital)

$=\quad$ EVA 


\section{Interpretasi Perhitungan EVA}

Dari perhitungan akan diperoleh kesimpulan dengan interpretasi hasil sebagai berikut:

- Jika EVA $>0$ hal ini menunjukkan terjadi nilai tambah ekonomis bagi perusahaan.

- Jika EVA $<0$ hal ini menunjukkan tidak terjadi nilai tambah ekonomis bagi perusahaan.

- Jika EVA = 0 hal ini menunjukkan posisi impas karena laba telah digunakan untuk membayar kewajiban kepada penyandang dana baik kreditur maupun pemegang saham.

\section{Keunggulan dan Kelemahan EVA}

Salah satu keunggulan EVA sebagai penilai kinerja perusahaan adalah dapat digunakan sebagai penciptaan nilai (value creation). Keunggulan EVA yang lain adalah (Iramani, 2005):

1. EVA memfokuskan penilaian pada nilai tambah dengan memperhitungkan beban sebagai konsekuensi investasi.

2. Konsep EVA adalah alat perusahaan dalam mengukur harapan yang dilihat dari segi ekonomis dalam pengukurannya yaitu dengan memperhatikan harapan para penyandang dana secara adil dimana derajat keadilan dinyatakan dengan ukuran tertimbang dari struktur modal yang ada dan berpedoman pada nilai pasar dan bukan pada nilai buku.

3. Perhitungan EVA dapat dipergunakan secara mandiri tanpa memerlukan data pembanding seperti standar industri atau data perusahaan lain sebagai konsep penilaian.

4. Konsep EVA dapat digunakan sebagai dasar penilaian pemberian bonus pada karyawan terutama pada divisi yang memberikan EVA lebih sehingga dapat dikatakan bahwa EVA menjalankan stakeholders satisfaction concepts.

5. Pengaplikasian EVA yang mudah menunjukan bahwa konsep tersebut merupakan ukuran praktis, mudah dihitung, dan mudah digunakan sehingga merupakan salah satu bahan pertimbangan dalam mempercepat pengambilan keputusan bisnis.

Selain berbagai keunggulan, konsep EVA juga memiliki kelemahankelemahan, antara lain:

1. EVA hanya mengukur hasil akhir (result), konsep ini tidak mengukur aktivitas-aktivitas penentu. 
2. EVA terlalu bertumpu pada keyakinan bahwa investor sangat mengandalkan pendekatan fundamental dalam mengkaji dan mengambil keputusan untuk menujual atau membeli saham tertentu padahal factor-faktor lain terkdang justru lebih dominan.

\section{FVA}

Financial Economic Value Added atau lebih singkat disebut Financial value Added (FVA) merupakan metode baru dalam mengukur kinerja dan nilai tambah keuangan. Financial Value Added adalah selisih antara laba operasi setelah pajak (NOPAT) dengan equivalent depreciation yang telah dikurangi dengan penyusutan. Hasil perhitungan FVA yang positif menunjukan bahwa keuntungan bersih dan penyusutan dapat menutupi equivalent depreciation. Jika hal ini terjadi maka perusahaan akan dapat meningkatkan pengembalian atas modal yang telah ditanamkan di dalam perusahaan sehingga akan dapat meningkatkan kekayaan pemegang sahamnya. Metode ini mempertimbangkan kontribusi dari fixed asset dalam menghasilkan keuntungan bersih perusahaan (Iramani, 2005).

\section{Interpretasi Perhitungan FVA}

Interpretasi dari hasil pengukuran FVA dapat dijelaskan sebagai berikut (Iramani, 2005):

- Jika FVA $>0$ hal ini menunjukkan terjadi nilai tambah finansial bagi perusahaan.

- Jika FVA < 0 hal ini menunjukkan tidak terjadi nilai tambah finansial bagi perusahaan.

- Jika FVA = 0 hal ini menunjukkan posisi impas.

\section{Keunggulan dan Kelemahan FVA}

Kelebihan FVA dibanding EVA adalah (Iramani, 2005):

1. Jika ditilik ulang konsep NOPATD, FVA melalui defenisi equivalent depreciation mengintegrasikan seluruh kontribusi aset bagi kinerja perusahaan, demikian juga opportunity cost bagi pembiayaan perusahaan. Kontribusi ini konstan selama umur proyek investasi.

2. FVA secara jelas mengakomodasikan kontribusi konsep value growth duration (durasi proses penciptaan nilai) sebagai unsur penambahan nilai. Unsur ini merupakan hasil pengurangan nilai equivalent depreciation akibat bertambah panjang umur aset dimana aset bisa terus berkontribusi bagi kinerja perusahaan. Dalam konsep EVA, proses ini tidak secara jelas dijabarkan. 
3. FVA mengedepankan konsep equivalent depreciation dan accumulated equivalent tampaknya lebih akurat menggambarkan financing costs. Lebih lanjut, FVA mampu mengharmoniskan hasilnya dengan konsep net present value (NPV) tahun per tahun, dimana NPV setidaknya saat ini dianggap sukses mengukur proses penciptaan nilai.

4. Dengan berbasis pada definisi EVA yang sudah dikenal luas, FVA memberi solusi terhadap mekanisme kontrol dalam periode tahunan, yang selama ini merupakan kendala bagi konsep NPV. EVA dan FVA sama-sama mampu menyelaraskan output-nya dengan hasil NPV, dalam bentuk periode yang terdiskonto, namun FVA memberi output lebih maju dengan berhasil melakukan harmonisasi hasil dengan NPV dalam ukuran tahunan. Oleh karena itu, FVA menjadi lebih bermanfaat sebagai alat kontrol.

Kelemahan FVA dibandingkan EVA, FVA kurang praktis dalam mengantisipasi fenomena bila perusahaan menjalankan investasi baru di tengah-tengah masa investasi diperhitungkan. EVA akan merefleksikan situasi ini melalui peningkatan aset dan sumber daya yang terlibat dalam perusahaan atau proyek. Fenomena ini tidak biasa diakomodasi dalam penentuan titik impas pada konsep NPV dan FVA (Iramani, 2005).

\section{METODOLOGI}

\section{Metode Analisis}

a. Metode Penelitian Kepustakaan

Dilakukan dengan membaca buku-buku dan artikel yang menunjang untuk kepentingan landasan teori dalam mendukung analisis yang dilakukan, dan data-data keuangan perusahaan untuk kebutuhan analisis.

b. Metode Analisis Data

Metode analisis data yang digunakan penulis untuk menganalisis data yang telah dikumpulkan adalah metode analisis deskriptif. Metode analisis deskriptif atau statistik deskriptif adalah satatistik yang digunakan untuk menganalisis data dengan cara mendeskripsikan atau menggambarkan data yang telah terkumpul sebagaimana adanya tanpa bermaksud membuat kesimpulan yang berlaku untuk umum atau generalisasi mengenai keadaan perusahaan melalui pengumpulan, menyusun, dan menganalisis data tentang masalah yang ada. 


\section{Variabel dan Pengukuran}

Variabel yang digunakan dalam penelitian ini adalah kinerja keuangan perusahaan dengan indikator metode EVA dan FVA.

a. Pengukuran Economic Value Added (EVA)

Berikut ini adalah langkah-langkah untuk mengukur EVA:

1. Menghitung NOPAT

Rumus NOPAT (Tunggal, 2008, p6):

NOPAT $=$ Laba Bersih Setelah Pajak + Beban Bunga

(1)

2. Menghitung Biaya Hutang (Cost of Debt $\longrightarrow \mathrm{k}_{\mathrm{dt}}$ )

Rumus Cost of Debt (Brigham, 1994, p106):

$$
\mathrm{k}_{\mathrm{dt}}=\mathrm{k}_{\mathrm{d}} \times(1-\mathrm{T})
$$

Dimana:

$$
\begin{aligned}
\mathrm{k}_{\mathrm{dt}} & =\text { Biaya hutang setelah pajak } \\
\mathrm{k}_{\mathrm{d}} & =\text { Biaya hutang sebelum pajak } \\
\mathrm{T} & =\text { Tarif pajak }
\end{aligned}
$$

3. Menghitung Biaya Modal Sendiri (Cost of Equity $\longrightarrow \mathrm{k}_{\mathrm{s}}$ )

Rumus Cost of Equity (Brigham, 1994, p110) :

Dimana:

$$
\mathrm{ks}=\mathrm{k}_{\mathrm{Rf}}+\left(\mathrm{k}_{\mathrm{Rm}}-\mathrm{k}_{\mathrm{Rf}}\right) \beta
$$

ks $=$ Tingkat pengembalian yang diinginkan investor (opportunity of equity)

$\mathrm{k}_{\mathrm{Rf}} \quad=$ Tingkat bunga investasi yang diperoleh tanpa resiko (risk free)

$\mathrm{k}_{\mathrm{Rm}} \quad=$ Tingkat bunga investasi rata-rata dari pasar

$\beta=$ Ukuran resiko saham perusahaan

4. Menghitung Rata-Rata Tertimbang dari Biaya Modal (Weighted Average Cost of Capital $\longrightarrow$ WACC)

Rumus Weighted Average Cost of Capital (Tunggal, 2008, p4):

Dimana:

$$
\mathrm{r}_{\mathrm{A}}=(\mathrm{D} / \mathrm{V} \mathrm{x} \mathrm{k \textrm {dt }})+(\mathrm{E} / \mathrm{V} \mathrm{x} \mathrm{ks})
$$

$$
\begin{aligned}
& \mathrm{r}_{\mathrm{A}}=\mathrm{WACC}=\text { Weighted Average Cost of Capital } \\
& \mathrm{D}=\text { Debt } \\
& \mathrm{E}=\text { Equity } \\
& \mathrm{V}=\mathrm{D}+\mathrm{E} \\
& \mathrm{k}_{\mathrm{dt}}=\text { Biaya hutang setelah pajak } \\
& \mathrm{ks}=\text { Tingkat pengembalian yang diinginkan investor } \\
& \text { (opportunity of equity) }
\end{aligned}
$$

5. Menghitung Invested Capital

Rumus Invested Capital (Tunggal, 2008, p5): 
Invested Capital $=$ pinjaman jangka pendek + pinjaman jangka panjang lainnya (interest bearing liabilities) + ekuitas pemegang saham

6. Menghitung Economic Value Added (EVA)

Rumus Economic Value Added (Tunggal, 2008, p2):

Dimana:

$$
\mathrm{EVA}=\text { NOPAT }- \text { Capital Charges }
$$

NOPAT = Net Operating After Tax

Capital Charges = Invested Capital x WACC

b. Pengukuran Financial Value Added (FVA)

Berikut ini langkah-langkah mengukur FVA:

1. Menghitung Total Resources (TR)

Rumus Total resources (Iramani, 2005):

$$
\mathrm{TR}=\mathrm{D}+\mathrm{E}
$$

Dimana:

$\mathrm{D}=$ Long term debt

$\mathrm{E} \quad=$ Total equity

2. Menghitung Equivalent Depreciation (ED)

Rumus Equivalent Depreciation (Sandias, 2002):

$$
\mathrm{ED}=\mathrm{k} \times \mathrm{TR}
$$

Dimana:

$\mathrm{k}=$ Biaya modal rata-rata tertimbang (WACC)

$\mathrm{TR}=$ Total resources

3. Menghitung Financial Value Added (FVA)

Rumus Financial Value Added (Sandias, 2002):

$$
\mathrm{FVA}=\mathrm{NOPAT}-(\mathrm{ED}-\mathrm{D})
$$

Dimana:

NOPAT = Net Operating After Tax

$\mathrm{ED}=$ Equivalent depreciation

$\mathrm{D} \quad=$ Depresiasi

\section{Metode Pengumpulan Data}

Teknik pengumpulan data yang dilakukan penulis dalam penelitian ini adalah dengan studi dokumentasi pada laporan keuangan 2004-2009 perusahaan-perusahaan industri perkebunan yang didapat langsung dari IDX (www.idx.co.id). 


\section{PEMBAHASAN}

\section{Analisis Economic Value Added (EVA) dan Financial Value Added (FVA) pada Industri Perkebunan}

Setelah dihitung nilai economic value added (EVA) dan financial value added (FVA) pada sub bab di atas, dimana populasi yang diambil adalah industri perkebunan dengan sampel lima perusahaan go public yaitu PT Astra Agro Lestari Tbk, PT SMART Tbk, PT Tunas Baru Lampung Tbk, PT Bakrie Sumatera Plantations Tbk, PT London Sumatera Indonesia Tbk pada periode tahun 2004-2009. Maka selanjutnya akan dianalisis secara keseluruhan dari lima sampel tersebut kinerja keuangannya baik dari metode EVA dan FVA.

Pada tabel 1 dapat dilihat pada tahun 2004 rata-rata EVA perusahaanperusahaan go public pada industri perkebunan bernilai positif yaitu Rp 15.184.915.572,- hal ini membuktikan bahwa pada tahun 2004 industri perkebunan secara umum memiliki kinerja keuangan yang baik. Walaupun untuk PT Tunas Baru Lampung tbk dan PT SMART tbk memiliki nilai EVA yang negatif pada tahun 2004, tetapi perusahaan lainnya memiliki nilai EVA yang positif.

Tabel 1. EVA 2004-2009

*(Dalam rupiah)

\begin{tabular}{|l|l|l|l|}
\hline \multicolumn{2}{|l}{ EVA } \\
\hline & AALI $^{*}$ & LSIP $^{*}$ & TBLA $^{*}$ \\
\hline 2004 & 247.900 .000 .000 & 108.950 .000 .000 & $(139.691 .301 .000)$ \\
\hline 2005 & 443.141 .000 .000 & 175.144 .000 .000 & $(49.602 .365 .000)$ \\
\hline 2006 & $(215.895 .000 .000)$ & $(232.684 .000 .000)$ & $(348.784 .195 .000)$ \\
\hline 2007 & $(5.863 .000 .000)$ & $(106.751 .000 .000)$ & $(32.998 .941 .000)$ \\
\hline 2008 & 8.308 .369 .000 .000 & 4.699 .166 .000 .000 & 982.047 .779 .000 \\
\hline 2009 & $(3.915 .519 .000 .000)$ & $(2.624 .930 .000 .000)$ & 162.866 .364 .000 \\
\hline
\end{tabular}

\begin{tabular}{|c|c|c|c|}
\hline \multicolumn{4}{|c|}{ EVA ( continu e ) } \\
\hline & SMART $^{*}$ & UNSP* $^{*}$ & Rata-Rata per Tahun* \\
\hline 2004 & (188.130.717.138) & 46.896 .596 .000 & 15.184.915.572 \\
\hline 2005 & (289.119.807.618) & 61.057 .367 .000 & 68.124 .038 .876 \\
\hline 2006 & (327.339.999.053) & (102.824.819.000) & (245.505.602.611) \\
\hline 2007 & 263.747 .036 .174 & (882.352.230.000) & $(152.843 .626 .965)$ \\
\hline 2008 & 3.047 .028 .275 .972 & 31.971 .828 .000 & 3.413 .716 .576 .594 \\
\hline 2009 & $(2.077 .277 .410 .862)$ & $(2.884 .296 .945 .000)$ & $(2.267 .831 .398 .372)$ \\
\hline \multicolumn{3}{|c|}{ Total Rata-rata EVA } & 138.474.150.516 \\
\hline
\end{tabular}

Sumber: Laporan Keuangan 2004-2009 yang telah diolah penulis 
Pada tahun 2005 rata-rata EVA perusahaan-perusahaan go public pada industri perkebunan mengalami kenaikan yaitu dari Rp 15.184.915.572,pada tahun 2004 menjadi Rp 68.124.038.876,- pada tahun 2005. Dikarenakan nilai EVA masih bernilai positif, maka bisa dibilang kinerja keuangan pada industri perkebunan secara umum memiliki kinerja keuangan yang baik. Walaupun untuk PT Tunas Baru Lampung tbk dan PT SMART tbk memiliki nalai EVA yang negatif pada tahun 2004, tetapi perusahaan lainnya memiliki nilai EVA yang positif.

Pada tahun 2006 nilai rata-rata EVA perusahaan-perusahaan go public pada industri perkebunan mengalami penurunan hingga bernilai negatif yaitu menjadi negatif $\mathrm{Rp}$ 245.505.602.611,-. Hal ini membuktikan bahwa pada tahun 2006 industri perkebunan secara umum memilki kinerja keuangan yang kurang baik, dapat dilihat pada tahun 2006 ke lima perusahaan bernilai negatif.

Pada tahun 2007 nilai rata-rata EVA perusahaan-perusahaan go public pada industri perkebunan masih bernilai negatif yaitu negatif Rp 152.843.626.965,-. Hal ini membuktikan bahwa pada tahun 2007 industri perkebunan secara umum memilki kinerja keuangan yang kurang baik, dapat dilihat pada tahun 2007 hampir seluruh perusahaan EVAnya bernilai negatif, hanya PT SMART tbk yang EVAnya bernilai positif.

Pada tahun 2008 rata-rata EVA perusahaan-perusahaan go public pada industri perkebunan mengalami kenaikan yaitu dari negatif Rp 152.843.626.965,- pada tahun 2007 menjadi Rp 3.413.716.576.594,- pada tahun 2008. Dikarenakan nilai EVA bernilai positif, maka bisa dibilang kinerja keuangan pada industri perkebunan secara umum memiliki kinerja keuangan yang baik. Pada tahun 2008 ini kelima perusahaan memiliki nial EVA yang positif.

Pada tahun 2009 nilai rata-rata EVA perusahaan-perusahaan go public pada industri perkebunan turun menjadi bernilai negatif yaitu negatif $\mathrm{Rp}$ 2.267.891.398.372,-. Hal ini membuktikan bahwa pada tahun 2009 industri perkebunan secara umum memilki kinerja keuangan yang kurang baik, dapat dilihat pada tahun 2009 hampir seluruh perusahaan EVAnya bernilai negatif, hanya PT Tunas Baru Lampung tbk yang EVAnya bernilai positif.

Pada tabel 2 dapat dilihat pada tahun 2004 rata-rata FVA perusahaanperusahaan go public pada industri perkebunan bernilai positif yaitu Rp 162.965.301.251,- hal ini membuktikan bahwa pada tahun 2004 industri perkebunan secara umum memiliki kinerja keuangan yang baik. 
Walaupun untuk PT Tunas Baru Lampung tbk dan PT SMART tbk memiliki nalai FVA yang negatif pada tahun 2004, tetapi perusahaan lainnya memiliki nilai FVA yang positif.

Pada tahun 2005 rata-rata EVA perusahaan-perusahaan go public pada industri perkebunan mengalami kenaikan yaitu dari Rp 162.965.301.251,pada tahun 2004 menjadi Rp 229.326.718.568,- pada tahun 2005. Dikarenakan nilai FVA masih bernilai positif, maka bisa dibilang kinerja keuangan pada industri perkebunan secara umum memiliki kinerja keuangan yang baik. Pada tahun 2005 kelima perusahaan memiliki nilai FVA yang positif.

Pada tahun 2006 nilai rata-rata FVA perusahaan-perusahaan go public pada industri perkebunan mengalami penurunan hingga bernilai negatif yaitu menjadi negatif Rp 14.989.187.748,-- Hal ini membuktikan bahwa pada tahun 2006 industri perkebunan secara umum memilki kinerja keuangan yang kurang baik, dapat dilihat pada tahun 2006 hampir ke lima perusahaan bernilai negatif hanya PT Astra Agro Lestari tbk yang memiliki nilai FVA positif.

Tabel 2. FVA 2004-2009

*(Dalam rupiah)

\begin{tabular}{|l|l|l|l|}
\hline \multicolumn{2}{|l|}{ FVA } \\
\hline & AALI $^{*}$ & LSIP $^{*}$ & TBLA $^{*}$ \\
\hline 2004 & $565,344,000,000$ & $260,069,000,000$ & $(44,389,793,000)$ \\
\hline 2005 & $610,628,000,000$ & $302,401,000,000$ & $37,521,451,000$ \\
\hline 2006 & $81,318,000,000$ & $(231,000,000)$ & $(111,391,655,000)$ \\
\hline 2007 & $545,586,000,000$ & $105,088,000,000$ & $(58,444,357,000)$ \\
\hline 2008 & $7,589,121,000,000$ & $4,126,038,000,000$ & $763,377,559,000$ \\
\hline 2009 & $(2,972,787,000,000)$ & $(2,289,937,000,000)$ & $304,676,026,000$ \\
\hline
\end{tabular}

\begin{tabular}{|l|l|l|l|}
\hline \multicolumn{5}{|c|}{ FVA ( c o n t i n u e ) } \\
\hline & SMART $^{*}$ & UNSP $^{*}$ & Rata-rata per Tahun $^{*}$ \\
\hline 2004 & $(72,372,866,746)$ & $106,176,166,000$ & 162.965 .301 .251 \\
\hline 2005 & $95,931,697,840$ & $100,151,444,000$ & 229.326 .718 .568 \\
\hline 2006 & $(5,199,075,740)$ & $(39,442,208,000)$ & $(14.989 .187 .748)$ \\
\hline 2007 & $618,653,996,136$ & $(637,330,110,000)$ & 114.710 .705 .827 \\
\hline 2008 & $3,257,651,961,561$ & $29,660,047,000$ & 3.153 .169 .713 .512 \\
\hline 2009 & $(1,011,470,424,833)$ & $(2,391,167,357,000)$ & $(1.672 .137 .151 .167)$ \\
\hline \multicolumn{3}{|l}{ Total Rata-rata FVA } & $\mathbf{3 2 8 . 8 4 1 . 0 1 6 . 7 0 7}$ \\
\hline
\end{tabular}

Sumber: Laporan Keuangan 2004-2009 yang diolah penulis 
Pada tahun 2007 nilai rata-rata FVA perusahaan-perusahaan go public pada industri perkebunan mengalami kenaikan hingga bernilai positif yaitu Rp 114.710.705.827,-. Hal ini membuktikan bahwa pada tahun 2007 industri perkebunan secara umum memilki kinerja keuangan yang baik, dapat dilihat pada tahun 2007 hampir seluruh perusahaan FVAnya bernilai positif, hanya PT Tunas Baru Lampung tbk dan PT Bakrie Sumatera Plantations tbk yang FVAnya bernilai positif.

Pada tahun 2008 rata-rata FVA perusahaan-perusahaan go public pada industri perkebunan mengalami kenaikan yaitu menjadi Rp 3.153.169.713.512,- pada tahun 2008. Dikarenakan nilai FVA bernilai positif, maka bisa dibilang kinerja keuangan pada industri perkebunan secara umum memiliki kinerja keuangan yang baik. Pada tahun 2008 ini kelima perusahaan memiliki nial FVA yang positif.

Pada tahun 2009 nilai rata-rata EVA perusahaan-perusahaan go public pada industri perkebunan turun menjadi bernilai negatif yaitu negatif $\mathrm{Rp}$ 1.672.137.151.167,-. Hal ini membuktikan bahwa pada tahun 2009 industri perkebunan secara umum memiliki kinerja keuangan yang kurang baik, dapat dilihat pada tahun 2009 hampir seluruh perusahaan FVAnya bernilai negatif, hanya PT Tunas Baru Lampung tbk yang FVAnya bernilai positif.

\section{Analisis dan Pengujian Statistik}

Ada dua metode yang dapat digunakan untuk menguji suatu hipotesis, yaitu metode statistik parametik dan metode non parametik. Metode statistik parametik digunakan jika data yang dimiliki merupakan data kuantitatif dan berjumlah lebih atau sama dengan 30, jika tidak maka harus digunakan metode non parametik. Berdasarkan jumlah data penelitian yang dimiliki yaitu 30 dan merupakan data kuantitatif, maka metode analisis yang digunakan adalah statistik parametik yaitu uji-t dengan menggunakan perangkat lunak SPSS.

Hipotesis:

$\mathrm{H} 0: \mu_{1}=\mu_{2}$

Tidak ada perbedaan yang signifikan antara kinerja keuangan perusahaan yang diukur dengan menggunakan economic value added (EVA) dan kinerja keuangan perusahaan yang diukur dengan financial value added (FVA).

$\mathrm{H} 1: \mu_{1} \neq \mu_{2}$

Terdapat perbedaan yang signifikan antara kinerja keuangan perusahaan yang diukur dengan menggunakan economic value 
added (EVA) dan kinerja keuangan perusahaan yang diukur dengan financial value added (FVA).

Dasar pengambilan keputusan:

H0 diterima jika: $\operatorname{sig}>0,05$

H0 ditolak jika: sig $<0,05$

Untuk uji dua sisi, setiap sisi dibagi 2 hingga menjadi

H0 diterima jika: sig $>0,025$

H0 ditolak jika: sig $<0,025$

Selanjutnya berdasarkan data-data dari perhitungan di atas, maka didapat hasil dari perhitungan statistik uji t yang menggunakan SPSS sebagai berikut:

Tabel 3. Paired Samples Statistics

\begin{tabular}{|rr|r|r|r|r|}
\hline & & Mean & $\mathrm{N}$ & Std. Deviatior & Std. Error Mea \\
\hline Pair 1 & EVA & $1.42 \mathrm{E}$ & & $2.175 \mathrm{E}$ & $3.970 \mathrm{~B}$ \\
& FVA & $3.29 \mathrm{E}$ & & $1.907 \mathrm{E}$ & $3.482 \mathrm{~B}$ \\
\hline
\end{tabular}

Sumber : hasil perhitungan SPSS

Tabel 4. Paired Samples Correlations

\begin{tabular}{|c|c|c|c|}
\hline & $\mathrm{N}$ & Correlation & Sig. \\
\hline Pair 1 EVA \& FVA & & .9 & \\
\hline
\end{tabular}

Sumber : hasil perhitungan SPSS

Tabel 5. Paired Samples Test

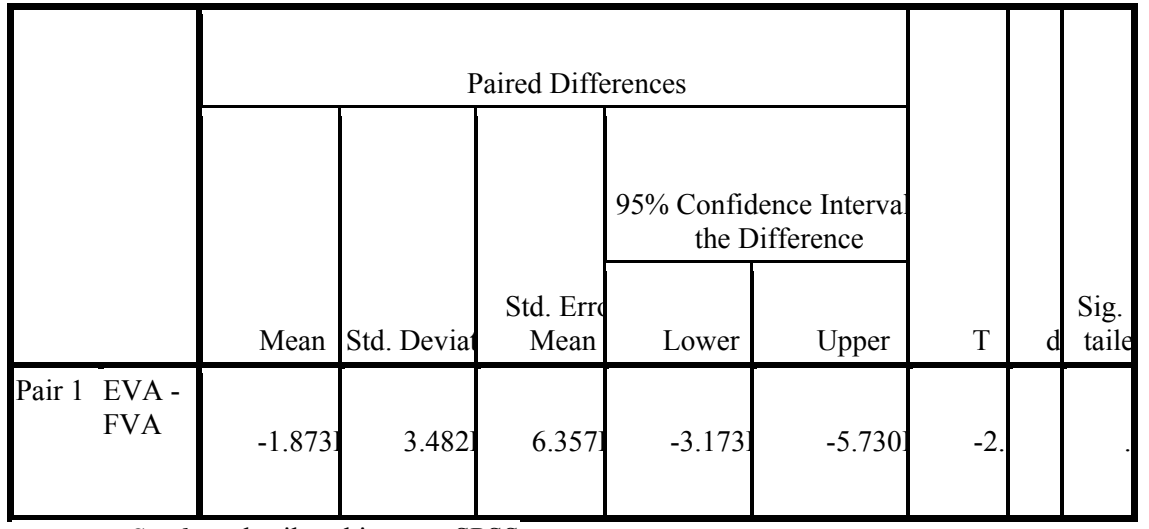

Sumber : hasil perhitungan SPSS 
Dari perhitungan statistik di atas, maka dapat diperoleh jumlah nilai dari sig $=0,006$ karena pengujian dua arah sig dibagi dua yatu menjadi $0,006 / 2=0,003$. Menurut kriteria pengujian yaitu:

H0 diterima jika : sig $>0,025$

H0 ditolak jika : sig $<0,025$

Sehingga hipotesis alternatif (Ha) diterima atau hipotesis nol (H0) ditolak, karena sig lebih kecil dari $0,025(0,003<0,025)$, yang berarti ada perbedaan yang signifikan antara penilaian kinerja keuangan industri perkebunan yang diukur menggunakan economic value added (EVA) dengan kinerja keuangan industri perkebunan yang diukur dengan financial value added (FVA).

Walaupun adanya perbedaan yang cukup signifikan tetapi hasil perhitungan statistik membuktikan nilai korelasi diantaranya sebesar 0,994 hampir mendekati angka satu yang terdapat pada table 4 di atas, yang berarti EVA dan FVA hampir memiliki pola yang sama.

\section{KESIMPULAN DAN SARAN}

\section{Kesimpulan}

EVA merupakan suatu pengukuran yang menunjukkan adanya proses penciptaan nilai dari suatu investasi. Untuk mengetahui kinerja perusahaan-perusahaan yang bergerak di Industri Perkebunan yang terdaftar di Bursa Efek Indonesia selama periode 2004 - 2009, maka dapat dilihat nilai EVA yang dihasilkan dan dapat dibandingkan dengan nilai FVA. Pengukuran FVA juga ditujukan untuk menggambarkan kontribusi aktiva tetap dalam menghasilkan nilai bagi perusahaan. Sebelum mengakhiri penelitian ini, penulis mencoba memberikan beberapa kesimpulan berikut saran-saran yang merupakan rangkuman atas uraian dan pembahasan yang telah dikemukakan.

Berdasarkan uraian yang telah disebutkan sebelumnya, maka dapat diambil beberapa kesimpulan sebagai berikut :

1. Berdasarkan hasil analisis EVA pada perusahaan-perusahaan go public yang bergerak pada industri perkebunan untuk periode tahun 2004-2009, rata-rata nilai EVA dari lima perusahaan yaitu PT Astra Agro Lestari Tbk, PT SMART Tbk, PT Tunas Baru Lampung Tbk, PT Bakrie Sumatera Plantations Tbk, PT London Sumatera Indonesia Tbk memberikan nilai EVA yang positif. Hal ini berarti industri perkebunan memiliki kinerja keuangan yang baik, dikarenakan hampir dari perusahaan-perusahaan go public 
tersebut telah mampu menutupi biaya modal yang dikeluarkan oleh perusahaan dengan laba usaha setelah pajak (NOPAT), artinya menajemen perusahaan telah mampu menciptakan nilai tambah ekonomi bagi perusahaannya

2. Berdasarkan hasil analisis FVA pada perusahaan-perusahaan go public yang bergerak pada industri perkebunan untuk periode tahun 2004-2009, rata-rata nilai FVA dari lima perusahaan yaitu PT Astra Agro Lestari Tbk, PT SMART Tbk, PT Tunas Baru Lampung Tbk, PT Bakrie Sumatera Plantations Tbk, PT London Sumatera Indonesia Tbk memberikan nilai FVA yang positif. Hal ini berarti industri perkebunan memiliki kinerja keuangan yang baik, dikarenakan laba usaha setelah pajak (NOPAT) dan nilai depresiasi telah mampu menutupi nilai equivalent depreciation perusahaan, artinya menajemen perusahaan telah mampu menciptakan nilai tambah finansial bagi perusahaannya

3. Berdasarkan perhitungan statistik yaitu uji $\mathrm{T}$, didapat hasil bahwa terdapat perbedaan yang signifikan antara penilaian kinerja keuangan berdasarkan metode EVA dan FVA, walaupun secara korelasi hampir memiliki pola yang sama. Hasil kedua perhitungan menandakan positif dimana berarti kinerja keuangan perusahaan-perusahaan go public pada industri perkebunan untuk periode 2004-2009 memiliki kinerja keuangan yang baik, tetapi nilai FVA lebih besar dibandingkan dengan nilai EVA. Besarnya nilai FVA dibanding EVA dikarenakan dalam perhitungan laba perusahaan berdasarkan FVA perusahaan memperhitungkan kontribusi aset tetap dalam menghasilkan keuntungan bersih perusahaan yaitu depresiasi yang dimasukan sebagai faktor penambah. Sedangkan perhitungan laba perusahaan berdasarkan EVA perusahaan hanya mengukur bagaimana laba usaha setelah pajak mampu menutupi biaya modal yang dikeluarkan perusahaan untuk memperoleh tambahan modalnya. Jadi, semakin menurunnya biaya modal perusahaan akan menyebabkan EVA perusahaan meningkat pula.

\section{Saran}

Adapun saran-saran yang peneliti coba ajukan untuk dapat dijadikan bahan masukan yang berguna bagi pihak-pihak yang berkepentingan, yaitu:

1. Perusahaan

$>$ Perusahaan sebaiknya dapat mengantisipasi setiap perubahan yang terjadi dikarenakan oleh faktor-faktor eksternal perusahaan seperti tingkat bunga yang berlaku, kondisi 
perekonomian beik secara mikro maupun makro dan lain sebagainya.

> Perusahaan-perusahaan sebaiknya menerapkan sistem EVA atau FVA agar lebih dapat menciptakan peningkatan kekayaan (create value) bagi perusahaan atau pemegang sahamnya. Selain itu dengan memasukan nilai EVA atau FVA ke dalam laporan keuangan perusahaan, maka para investor dapat melihat nilai perusahaan yang sesungguhnya.

2. Penelitian selanjutnya

> Sebaiknya untuk penelitian selanjutnya dapat menggunakan tahun observasi serta sampel perusahaan yang lebih banyak sehingga dapat mengurangi distorsi perhitungan.

$>$ Sebaiknya melakukan persiapan terhadap data-data dan literatur-literatur yang diperlukan untuk menerapkan metode EVA atau FVA pada badan usaha yang diteliti.

\section{DAFTAR PUSTAKA}

Badan Pusat Statistik. (2010). Distribusi Persentase Produk Domestik Bruto Atas Dasar Harga Berlaku Menurut Lapangan Usaha. Diunduh 10 Mei 2010. www. bps.go.id

Brigham, Eugene \& J. Fred Weston. (1994). Dasar-Dasar Manajemen Keuangan Edisi Ke sembilan (Jilid 2). Jakarta. Erlangga.

Direktorat Jenderal Perkebunan. (2010). Luas Areal dan Produksi Perkebunan Seluruh Indonesia menurut Pengusahaan (Komoditi Kelapa Sawit). Diunduh $10 \quad$ Mei 2010. www.ditjenbun.deptan.go.id

Iramani, Rr. Febriani, Erie. (2005). Financial Value Added : Suatu Paradigma Baru Dalam Pengukuran Kinerja dan Nilai Tambah Perusahaan. Jurnal Akuntansi dan Keuangan, Vol. 7, No. 1, Hal. $1-10$.

Kementrian Perencanaan Pembangunan Nasional. (2010). Peraturan Presiden Republik Indonesia Nomor 5 Tahun 2010 Tentang Rencana Pembangunan Jangka Menengah Nasional (RPJM) Tahun 2010-2014. Diunduh 10 Mei 2010. www. bappenas.go.id 
Sandias, Rodriguez Alfonso. (2002). Financial Value Added. Retrieved 10 February 2010. www.ssrn.com

Stewart, Stern \& Co. (2010). Properti Intelektual : EVA \& MVA. Diunduh 1 April 2010. www.sternstewart.com

Tunggal, Amin Widjaja. (2008). Memahami Economic Value Added ( EVA ) Teori Soal dan Kasus. Jakarta: Harvarindo.

Young, David, S. \& F. Stephen O'Byrne. (2001). EVA and value based management: a practical guide to implementation. New York: McGraw-Hill.

Situs:

Website Bank Indonesia (http://www.bi.co.id)

Website Bursa Efek Indonesia (http;//www.idx.co.id)

Website Yahoo finance (http://www.finance.yahoo.com) 